\title{
Poultry
}

\section{Supplementation of Buttiauxella sp. 6-phytase to commercial laying hen diets with reduced nutrient density on productive performance and egg quality}

\author{
Yueming Dersjant-Li ${ }^{1}$, Carlos Millán ${ }^{2}$, Oscar Casabuena ${ }^{2}$, Alberto Quiles ${ }^{3}$, Luis F. Romero ${ }^{1}$ and \\ Marta I. Gracia ${ }^{2}$ \\ ${ }^{1}$ Danisco Animal Nutrition, DuPont Industrial Biosciences, Marlborough, UK \\ ${ }^{2}$ Imasde Agroalimentaria, S.L., C/ Nápoles 3, Pozuelo de Alarcón, 28224 Madrid, Spain \\ ${ }^{3}$ Department of Animal Science, University of Murcia, Campus de Espinardo, 30100 Murcia, Spain
}

\section{Summary}

A study was conducted to evaluate productive performance in laying hens fed diets with reduced nutrient density based on the nutritional contribution of a Buttiauxella phytase in laying-hen diets from 21-57 weeks of age. A commercial laying hen diet was offered ad libitum to the 480 ISA Brown laying hens from 18-21 weeks of age. From 21 weeks onwards, the hens received one of four dietary treatments: a positive control (PC) diet, a down specified diet (DS1) + phytase at $300 \mathrm{FTU} / \mathrm{kg}$, a second downspecified diet (DS2) + phytase at $600 \mathrm{FTU} / \mathrm{kg}$ and a third test diet formulated as per DS1 + phytase at 1,200 FTU/kg feed. The PC was formulated based on ISA breeder recommendations. DS1 was formulated with reduction of $0.149 \%$ available P, $0.134 \% \mathrm{Ca}, 55 \mathrm{kcal} / \mathrm{kg}$ AME, $0.33 \% \mathrm{CP}$, digestible amino acids (up to $0.015 \%$ ) and $0.013 \% \mathrm{Na}$ based on the contribution of Buttiauxella phytase at $300 \mathrm{FTU} / \mathrm{kg}$. DS2 was formulated with reduction of $0.177 \%$ available $\mathrm{P}, 0.159 \% \mathrm{Ca}, 60 \mathrm{kcal} / \mathrm{kg}$ AME, $0.61 \% \mathrm{CP}$, digestible amino acids (up to $0.028 \%$ ) and $0.02 \% \mathrm{Na}$ based on the contribution of Buttiauxella phytase at $600 \mathrm{FTU} / \mathrm{kg}$. Every dietary treatment was fed to 12 cages containing 10 hens each. The trial treatments did not include a full, DS negative control, as ethical considerations regarding birds' welfare when feeding such diets over such an extended period of time did not permit this. No significant differences were seen in hen-day egg production, feed intake, egg weight, feed to egg mass ratio, shell, yolk or albumen proportion, unsaleable eggs or shell breaking strength in laying hens fed the PC diet or the DS diets with added phytase. Yolk colour increased significantly with phytase supplementation. Supplementing the DS1 diet with 300 FTU and the DS2 diet with 600 FTU resulted in non-significant differences in tibia ash, $\mathrm{Ca}$ and P, compared to the PC diet. The data from this study indicated that applying the nutrient contributions for Buttiauxella phytase at 300 and $600 \mathrm{FTU} / \mathrm{kg}$ maintained the egg production, BW and egg quality parameters compared to PC. The best economic efficiency value during the whole experimental period was recorded with phytase at $600 \mathrm{FTU} / \mathrm{kg}$ when full matrix values are used. When commercial diets are formulated based on ISA breeder recommendations, lowering diet nutrient density while supplementing with phytase reduced the overall diet cost, which should contribute to the profitability of egg production.

Key words: Phytase: nutrient density: laying hens: bone ash: eggs

Statement of primary audience: nutritionists: researchers: veterinarians

(Received 3 April 2018 - Accepted 10 April 2018)

* Corresponding author: Yueming.dersjant-Li@dupont.com 


\section{Introduction}

Phytase is commonly supplemented in laying hen diets to improve phytate phosphorus (P) availability and retention and ultimately to reduce excretion (Ravindran et al., 2000, Jalal and Scheideler, 2001, Gao et al., 2013, Gosh et al., 2015). Phytate is the main phosphorus source in the plant-based feed ingredients, which not only has limited availability to laying hens, but can also reduce the availability of other nutrients. Phytate can complex with amino acids (Ravindran et al., 2000, Rutherfurd et al., 2004), starch and fat (Ravindran et al., 2001, Newkirk and Classen, 2001), thus reducing the absorption of these nutrients. In addition, phytate can interact with endogenous enzymes and result in a negative impact on $\mathrm{Na}$ and amino acid (AA) digestion and increase endogenous AA losses. Furthermore, in the intestine, phytate binds to $\mathrm{Ca}$ and other minerals, forming insoluble salts and rendering these minerals unavailable for absorption.

Phytase enzymes have the ability to hydrolyse phytate, releasing $\mathrm{P}$ which reduces the formation of phytatemineral complexes, increasing the bioavailability of minerals (Kornegay et al., 1996, Jalal and Scheideler, 2001). In addition to the $\mathrm{P}$ and $\mathrm{Ca}$ release, inclusion of phytase in the diet may reduce the negative impact of phytate on AA and starch digestion, improving digestibility of dietary AA and energy. Phytase supplementation improves the availability of nutrients such as protein and amino acids (Ravindran et al., 2000, Rutherfurd et al., 2004) and energy (Kornegay et al., 1996, Namkung and Leeson, 1999, Ravindran et al., 2000, 2001, Newkirk and Classen, 2001, Hughes et al., 2009) in poultry.

Some nutritionists apply only $\mathrm{P}$ and $\mathrm{Ca}$ contribution values for phytase, others consider the energy, dig AA and $\mathrm{Na}$ contribution to fully benefit from the supplementation. These contributions are called 'matrix values' when used during least cost formulation, indicating the amount of nutrients (amino acids, ME, P, Ca, Na) contributed by the addition of phytase to the diet (Shelton et al., 2004). The term 'full matrix' refers to applying dig AA, ME and $\mathrm{Na}$ contribution in addition to $\mathrm{P}$ and $\mathrm{Ca}$ contribution. When matrix values are used, diets can be formulated with a lower amount of $\mathrm{Ca}, \mathrm{P}$, crystalline amino acids and $\mathrm{ME}$, subsequently reducing the cost of feed (Shelton et al., 2004). Recent studies reported the benefit of increasing phytase dose in the diets for broilers and laying hens. $\mathrm{Li}$ et al. (2015, 2016) observed that increasing Buttiauxella phytase dose from 500 to 1000 FTU/kg increased phytate degradation rate, ileal $\mathrm{P}$ and AA digestibility and improved performance of animals in broilers. Truong et al. (2016) reported that increasing Buttiauxella phytase dose from 500 to $2000 \mathrm{FTU} / \mathrm{kg}$ further improved starch digestibility and body weight gain (BWG) in broilers. In laying hen diets phytase is traditionally supplemented at 300 FTU/ $\mathrm{kg}$ although recent studies showed that increased phytase dose in laying hens diets can further increase phytate $\mathrm{P}$ degradation, ileal $\mathrm{P}$ digestibility and reduce $\mathrm{P}$ excretion (White et al., 2016).

The main objective of the study was to evaluate the productive performance and egg quality parameters in laying hens fed diets with reduced nutrient density based on the nutritional contribution of a new generation Buttiauxella phytase at doses of 300 or $600 \mathrm{FTU} / \mathrm{kg}$ in a commercial trial with laying hens from 21 to 57 weeks of age. In addition, the effect of phytase at a higher dose level of 1,200 FTU/kg was tested, using the nutrient contribution of 300 FTU/kg. Laying performance, egg quality and bone mineralisation are normally influenced by dietary $\mathrm{P}$ levels and are sensitive indicators of mineral adequacy in the diet and were used as the response criteria.

\section{Materials and methods}

The experimental protocol was approved by the Research Ethical Committee of the University of Murcia and was performed in accordance with the recommendations specified in the Guide for the Care and Use of Agricultural Animals in Research and Teaching (FASS, 2010; http:// www.fass.org/).

\section{Animals and Housing}

At 18 weeks of age, a total of 480 Isa Brown laying hens were housed in laying cages under controlled climate conditions at the IMASDE Poultry Centre on the University of Murcia campus. Ten birds were placed in each cage (cage dimensions $63 \times 121 \mathrm{~cm}$ with a height of $45 \mathrm{~cm}$. The length of the light period was increased from 14L:10D to 16L:8D with a light intensity of 10 lux. The ambient temperature was maintained at a minimum of approximately $20^{\circ} \mathrm{C}$ throughout the trial. During the pre-experimental period (up to 21 weeks of age) a commercial laying hen diet was offered ad libitum, whereas from 21 weeks onwards, the hens were randomly assigned to one of the four dietary treatments (Table 1). Each dietary treatment was replicated 12 times with 10 hens per cage (replicate) in a randomised design. 
Table 1. Description of experimental treatments

\begin{tabular}{|c|c|c|c|}
\hline Treatment & $\begin{array}{l}\text { Basal } \\
\text { diet }\end{array}$ & Description & $\begin{array}{l}\text { Phytase FTU/ } \\
\text { kg feed }\end{array}$ \\
\hline T1 & PC & Normal ME, AA, Ca, P & 0 \\
\hline T2 & DS1 & $\begin{array}{l}\text { DS1 (Downspec } 300 \text { FTU) } \\
+300 \mathrm{FTU} / \mathrm{kg}\end{array}$ & 300 \\
\hline T3 & DS2 & $\begin{array}{l}\text { DS2 (Downspec } 600 \text { FTU) } \\
\text { + } 600 \mathrm{FTU} / \mathrm{kg}\end{array}$ & 600 \\
\hline T4 & DS1 & $\begin{array}{l}\text { DS1 (Downspec } 300 \text { FTU) } \\
+1,200 \mathrm{FTU} / \mathrm{kg}\end{array}$ & 1,200 \\
\hline
\end{tabular}

\section{Experimental Diets}

The ingredient and nutrient composition of the experimental diets is shown in Table 2. Three corn-wheatsoybean meal-based diets were formulated. The PC diet was formulated with adequate nutrients according to ISA breeder recommendation (2009) without phytase. The treatment diets DS1 and DS2 were formulated with reduction of available $\mathrm{P}, \mathrm{Ca}, \mathrm{AME}, \mathrm{CP}$, digestible amino acids and $\mathrm{Na}$, according to the nutritional

Table 2. Ingredients and nutrient composition of the experimental diets (as is) contribution of the phytase at dose 300 and 600 FTU/ $\mathrm{kg}$, respectively. Three levels of phytase were tested, a dose of $300 \mathrm{FTU} / \mathrm{kg}$ added to DS1, a dose of 600 FTU $/ \mathrm{kg}$ added to DS2 or a dose of $1,200 \mathrm{FTU} / \mathrm{kg}$ added to DS1 (Table 3). No negative control treatments were included due to the duration of the study, as it was not deemed ethical to feed nutrient deficient diets for 9 months period. It was considered that the trial design would still yield useful results in terms of practical applications of phytase enzyme and down specification matrix values, as the PC diets were formulated to be representative to current practical commercial diets. The phytase was a 6-phytase derived from Buttiauxella sp. (Danisco Animal Nutrition, DuPont Industrial Biosciences, Marlborough, UK). Experimental diets were fed from 21 to 57 weeks of age in three phases based on the requirement of the specific age of the laying hens (Table 2).

Birds had free access to feed and water throughout the experiment. Experimental diets were analysed for crude

\begin{tabular}{|c|c|c|c|c|c|c|c|c|c|}
\hline \multirow[b]{2}{*}{ Ingredients (\%) } & \multicolumn{3}{|c|}{$21-33$ weeks of age } & \multicolumn{3}{|c|}{$33-45$ weeks of age } & \multicolumn{3}{|c|}{$45-57$ weeks of age } \\
\hline & $\mathrm{PC}$ & DS1 & DS2 & $\mathrm{PC}$ & DS1 & DS2 & $\mathrm{PC}$ & DS1 & DS2 \\
\hline Corn & 29.32 & 33.34 & 34.75 & 35.39 & 39.41 & 40.81 & 35.78 & 39.80 & 41.20 \\
\hline Wheat & 21.0 & 21.0 & 21.0 & 20.0 & 20.0 & 20.0 & 20.0 & 20.0 & 20.0 \\
\hline Wheat middlings & 7.0 & 7.0 & 7.0 & 5.0 & 5.0 & 5.0 & 5.0 & 5.0 & 5.0 \\
\hline Rapeseed meal & 5.0 & 5.0 & 5.0 & 5.0 & 5.0 & 5.0 & 5.0 & 5.0 & 5.0 \\
\hline Soybean meal & 21.97 & 20.52 & 19.63 & 19.67 & 19.22 & 18.33 & 19.54 & 18.09 & 17.19 \\
\hline Lard & 5.338 & 3.521 & 3.150 & 3.65 & 1.83 & 1.46 & 3.762 & 1.945 & 1.574 \\
\hline Calcium carbonate & 8.197 & 8.187 & 8.188 & 8.258 & 8.249 & 8.249 & 9.106 & 9.097 & 9.097 \\
\hline Monocalcium phosphate & 1.224 & 0.508 & 0.378 & 1.117 & 0.401 & 0.271 & 0.982 & 0.266 & 0.136 \\
\hline Salt & 0.383 & 0.350 & 0.333 & 0.384 & 0.351 & 0.334 & 0.358 & 0.324 & 0.307 \\
\hline DL-methionine & 0.156 & 0.145 & 0.138 & 0.130 & 0.119 & 0.112 & 0.079 & 0.068 & 0.061 \\
\hline L-lysine $\mathrm{HCl}$ & - & 0.016 & 0.024 & - & 0.016 & 0.024 & - & 0.016 & 0.024 \\
\hline L- Threonine & 0.001 & 0.001 & - & 0.002 & 0.001 & - & - & - & - \\
\hline L-Tryptophan & 0.005 & 0.008 & 0.010 & - & 0.003 & 0.005 & - & 0.003 & 0.005 \\
\hline Vit\&min Premix ${ }^{1}$ & 0.400 & 0.400 & 0.400 & 0.400 & 0.400 & 0.400 & 0.400 & 0.400 & 0.400 \\
\hline \multicolumn{10}{|l|}{ Calculated nutrients ${ }^{2}(\%)$} \\
\hline $\mathrm{AME}_{\mathrm{n}}, \mathrm{kcal} / \mathrm{kg}$ & 2,780 & 2,725 & 2,720 & 2,735 & 2,680 & 2,675 & 2,730 & 2,675 & 2,670 \\
\hline Crude Protein & 16.84 & 16.51 & 16.23 & 16.30 & 15.97 & 15.69 & 15.80 & 15.47 & 15.19 \\
\hline Calcium & 3.60 & 3.47 & 3.44 & 3.60 & 3.47 & 3.34 & 3.90 & 3.77 & 3.74 \\
\hline Total phosphorus & 0.667 & 0.507 & 0.475 & 0.629 & 0.468 & 0.437 & 0.592 & 0.432 & 0.400 \\
\hline Phytate phosphorus & 0.275 & 0.277 & 0.276 & 0.264 & 0.265 & 0.264 & 0.260 & 0.261 & 0.260 \\
\hline Av. phosphorus & 0.380 & 0.231 & 0.203 & 0.350 & 0.201 & 0.173 & 0.320 & 0.171 & 0.143 \\
\hline Dig. lysine & 0.715 & 0.700 & 0.688 & 0.683 & 0.668 & 0.656 & 0.657 & 0.643 & 0.630 \\
\hline Dig. methionine & 0.384 & 0.372 & 0.362 & 0.355 & 0.343 & 0.33 & 0.299 & 0.287 & 0.277 \\
\hline Dig. Met+Cys & 0.626 & 0.611 & 0.598 & 0.592 & 0.577 & 0.564 & 0.530 & 0.515 & 0.502 \\
\hline Dig. threonine & 0.516 & 0.504 & 0.493 & 0.502 & 0.489 & 0.478 & 0.485 & 0.473 & 0.463 \\
\hline Dig. tryptophan & 0.178 & 0.176 & 0.174 & 0.165 & 0.163 & 0.162 & 0.160 & 0.158 & 0.156 \\
\hline \multicolumn{10}{|c|}{ Analysed nutrients, as-is basis (\%) } \\
\hline Crude protein & 17.6 & 17.2 & 16.6 & 16.8 & 16.3 & 16.2 & 15.7 & 15.4 & 15.8 \\
\hline Calcium & 4.05 & 3.64 & 3.63 & 3.72 & 3.46 & 3.34 & 4.05 & 3.89 & 3.80 \\
\hline Total phosphorus & 0.64 & 0.49 & 0.47 & 0.63 & 0.47 & 0.41 & 0.59 & 0.44 & 0.41 \\
\hline Phytate phosphorus & 0.263 & 0.234 & 0.218 & 0.242 & 0.238 & 0.227 & 0.221 & 0.210 & 0.199 \\
\hline
\end{tabular}

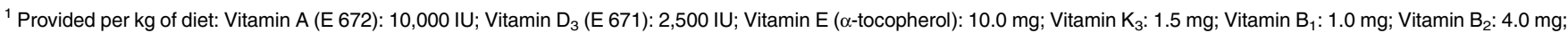
Vitamin $\mathrm{B}_{6}: 1.0 \mathrm{mg}$; Vitamin $\mathrm{B}_{12}: 18.0 \mu \mathrm{g} ;$ Nicotinic acid: $20.0 \mathrm{mg}$; Pantothenic acid: $7.0 \mathrm{mg}$; Choline chloride: $\left.\left.240 \mathrm{mg} ; \mathrm{Cu}_{(\mathrm{CuSO}} \cdot 5 \mathrm{H}_{2} \mathrm{O}\right): 10.0 \mathrm{mg} ; \mathrm{Fe}_{(\mathrm{FeSO}} \cdot \mathrm{H}_{2} \mathrm{O}\right): 60.0 \mathrm{mg} ;$ I (IK):

$3.0 \mathrm{mg} ; \mathrm{Mn}\left(\mathrm{MnSO}_{4} \cdot \mathrm{H}_{2} \mathrm{O}\right): 140 \mathrm{mg}$; $\mathrm{Se}\left(\mathrm{Na}_{2} \mathrm{SeO}_{3}\right): 0.10 \mathrm{mg} ; \mathrm{Zn}(\mathrm{ZnO}): 100 \mathrm{mg}$.

${ }_{2}$ Based on FEDNA (2010) values for feed ingredients. 
Table 3. Phytase contribution used for the formulation of test diets

\begin{tabular}{lcc}
\hline Parameter, \% & 300 FTU/kg (DS1) & 600 FTU/kg (DS2) \\
\hline AME $_{n}, \mathrm{kcal} / \mathrm{kg}$ & 55.18 & 60.22 \\
Crude Protein & 0.33 & 0.61 \\
Calcium & 0.134 & 0.159 \\
Total phosphorus & 0.157 & 0.186 \\
Av. Phosphorus & 0.149 & 0.177 \\
Sodium & 0.013 & 0.02 \\
Dig. Lysine & 0.0147 & 0.0271 \\
Dig. Methionine & 0.0046 & 0.0085 \\
Dig. Met+Cys & 0.0149 & 0.0275 \\
Dig. Threonine & 0.0128 & 0.0237 \\
Dig. Tryptophan & 0.002 & 0.0037 \\
\hline
\end{tabular}

protein, calcium and total phosphorus according to AOAC (2000) procedures. Feed samples were analysed for phytase activity prior to the study start by Danisco Innovation Laboratories (Brabrand, Denmark), using the method described by $\mathrm{Yu}$ et al. (2014). One phytase activity unit (FTU) is defined as the amount of enzyme that liberates one micromole of inorganic phosphate per minute from a sodium phytate substrate at $\mathrm{pH} 5.5$ at $37^{\circ} \mathrm{C}$.

\section{Data Collection}

Egg production was recorded on a replication basis daily. Eggs were classified as normal, broken, cracked and soft shelled. Classification was based on all the eggs collected daily. Egg weights were measured from all the eggs laid during one day every four weeks and calculated on a replication basis. Subsequently, the same eggs were used to assess shell percentage, yolk percentage, albumen percentage, yolk colour and eggshell breaking strength. Yolk colour was determined instrumentally by Minolta Chroma-meter (CR-300, Konica Minolta, Osaka, Japan) in the CIE $\mathrm{L}^{*} \mathrm{a}^{*} \mathrm{~b}^{*}$ space. The $\mathrm{L}^{*}$ value indicates the lightness, representing dark to light $(0-100)$. The $a^{*}$ (redness) value gives the degree of the red-green colour, with a higher positive $a^{*}$ value indicating a deeper red colour. The $\mathrm{b}^{*}$ (yellowness) value indicates the degree of the yellow-blue colour, with a higher positive $b^{*}$ value indicating more yellow. Shell breaking strength was measured using an Instron Testing Machine, Model 5542 (Instron Ltd., High Wycombe, UK), equipped with a $500 \mathrm{~N}$ load cell. The eggs were compressed at a constant crosshead speed of $10 \mathrm{~mm} / \mathrm{min}$ and the breaking strength was determined at the time of the eggshell fracture. Feed intake was determined on a replication basis by weighing back all feed every four weeks. Mortality was recorded daily on a replication basis. At the end of trial (57 weeks of age), the left tibia of one hen per replicate selected at random was removed, cleaned of adhering tissue, and frozen for determination of amount of tibia ash, $\mathrm{Ca}$ and P. The tibias were dried for $24 \mathrm{~h}$ at $105^{\circ} \mathrm{C}$, weighed, and defatted for $24 \mathrm{~h}$ with ethyl ether. The tibias were then dry-ashed for $24 \mathrm{~h}$ in a muffle furnace at $600^{\circ} \mathrm{C}$. Ash percentage of defatted left tibia and its relative $\mathrm{Ca}$ and $\mathrm{P}$ contents were determined after ashing at $600^{\circ} \mathrm{C}$, according to the method of AOAC (2000).

\section{Statistical Analyses}

Statistical analyses of data were performed using the GLM procedure of IBM SPSS Statistics for Windows Version 19.0. (IBM Corp., Armonk, NY). Duncan's multiple range test was used to separate the means when ANOVA was significant. Differences were considered significant when $\mathrm{P} \leq 0.05$.

\section{Results and discussion}

Feed analyses were within target values for crude protein, Ca and P for PC, DS1 and DS2 in each phase (Table 2). Phytase recovery analyses was variable among phases, but on average for the three phase diets values were within targets (309, 725 and 1,308 FTU/kg feed above PC diet for the treatments 300, 600 and 1,200 FTU/kg feed, respectively, Table 4).

No significant differences were found for hen-day egg production, feed intake, egg weight, feed to egg mass ratio, shell, yolk or albumen proportion, unsaleable eggs or shell breaking strength in laying hens fed the PC diet or the DS diets with added phytase (Table 4).

Beneficial effects of dietary phytase supplementation on egg production, feed intake and egg weight of laying hens have been reported (Panda et al., 2005, Hughes et al., 2008, Kozłowski and Jeroch, 2011, Valaja et al., 2013). In these studies, phytase was added to negative control diets with reduction of only $\mathrm{P}$, not with reduction of $\mathrm{Ca}$, dig $\mathrm{AA}$ and energy. The nutrient contribution values for phytase used in the present experiment included $\mathrm{Ca}$, available $\mathrm{P}, \mathrm{AME}, \mathrm{CP}$, dig $\mathrm{AA}$ and $\mathrm{Na}$. The availability of $\mathrm{Ca}$ (Jalal and Scheideler, 2001), P (Żyła et al., 2011, Gao et al., 2013, Gosh et al., 2015), energy (Ravindran et al., 2000, 2001, Newkirk and Classen, 2001, Hughes et al., 2009) and AA (Jalal et al., 1999, Liebert et al., 2005, Ravindran et al., 2001, 2006) has increased in laying hens when phytase is supplemented to the diets. The response observed in the present experiment suggested that the nutrients contribution values used for the tested phytase at given doses were 
Table 4. Effects of dietary treatments on productive performance, egg quality traits from 21 to 57 weeks of age and bone mineralisation of laying hens at 57 weeks of age

\begin{tabular}{|c|c|c|c|c|c|c|}
\hline $\begin{array}{l}\text { Treatment } \\
\text { Basal diet } \\
\text { Phytase, FTU/kg }\end{array}$ & $\begin{array}{l}\mathrm{P} \mathrm{P}^{\mathrm{T}} \\
0\end{array}$ & $\begin{array}{r}\text { T2 } \\
\text { DS1 } \\
300\end{array}$ & $\begin{array}{l}\text { T3 } \\
\text { DS2 } \\
600\end{array}$ & $\begin{array}{c}\text { T4 } \\
\text { DS1 } \\
1,200\end{array}$ & Probability & SEM \\
\hline Phytase FTU/kg (analysed)* & & 309 & 725 & 1308 & & \\
\hline BW at 21 weeks of age $(\mathrm{kg})$ & 1.69 & 1.68 & 1.70 & 1.70 & 0.8938 & 0.021 \\
\hline BW at 57 weeks of age $(\mathrm{kg})$ & 1.98 & 1.94 & 1.96 & 1.96 & 0.5858 & 0.024 \\
\hline Hen-day egg production (\%) & 87.8 & 85.4 & 87.0 & 87.5 & 0.5756 & 1.31 \\
\hline Feed intake $(\mathrm{g} / \mathrm{d})$ & 144.9 & 144.0 & 142.5 & 142.5 & 0.7332 & 1.79 \\
\hline Egg weight $(\mathrm{g})$ & 65.6 & 65.3 & 66.0 & 66.4 & 0.2810 & 0.42 \\
\hline Feed to egg mass ratio & 1.99 & 2.03 & 1.97 & 1.96 & 0.6504 & 0.041 \\
\hline Soft-shelled, cracked and broken eggs (\%) & 1.22 & 1.06 & 1.11 & 1.35 & 0.6461 & 0.172 \\
\hline Shell proportion (\%) & 12.7 & 12.8 & 12.9 & 12.8 & 0.6318 & 0.10 \\
\hline Yolk proportion (\%) & 24.5 & 24.6 & 24.4 & 24.3 & 0.6165 & 0.14 \\
\hline Albumen proportion (\%) & 62.8 & 62.6 & 62.7 & 62.9 & 0.7392 & 0.19 \\
\hline Yolk colour (L) & $46.7^{\mathrm{a}}$ & $46.4^{\mathrm{ab}}$ & $46.7^{\mathrm{a}}$ & $46.2^{b}$ & 0.0311 & 0.14 \\
\hline Yolk colour (a) & $17.7^{\mathrm{b}}$ & $18.8^{\mathrm{a}}$ & $18.7^{\mathrm{a}}$ & $18.8^{\mathrm{a}}$ & $<0.0001$ & 0.09 \\
\hline Yolk colour (b) & $37.0^{\mathrm{c}}$ & $38.0^{\mathrm{ab}}$ & $38.1^{\mathrm{a}}$ & $37.5^{\mathrm{bc}}$ & 0.0007 & 0.18 \\
\hline Shell breaking strength $(\mathrm{N})$ & 43.58 & 43.42 & 44.40 & 43.42 & 0.6491 & 0.634 \\
\hline Tibia ash & $54.5^{\mathrm{ab}}$ & $52.0^{\mathrm{b}}$ & $54.7^{\mathrm{ab}}$ & $55.5^{\mathrm{a}}$ & 0.0332 & 0.84 \\
\hline Tibia Ca & $20.65^{\mathrm{ab}}$ & $18.96^{\mathrm{b}}$ & $19.84^{\mathrm{ab}}$ & $23.25^{\mathrm{a}}$ & 0.0140 & 0.931 \\
\hline Tibia P & $9.19^{\mathrm{ab}}$ & $8.46^{\mathrm{b}}$ & $8.52^{\mathrm{b}}$ & $10.02^{\mathrm{a}}$ & 0.0179 & 0.378 \\
\hline
\end{tabular}

a-c Means within a row with different superscripts are significantly different $(P<0.05)$.

${ }^{*}$ Average of three phases and after subtract the basal phytase levels in PC

applicable when laying hen performance and egg quality traits were used as response variables, using the current trial settings for a nine-month trial duration. These results indicated that phytase overcame the nutrient reduction in DS diets and maintained production performance comparable to PC.

Yolk colour, expressed as lightness $\left(\mathrm{L}^{*}\right)$, redness $\left(\mathrm{a}^{*}\right)$ and yellowness $\left(\mathrm{b}^{*}\right)$, increased significantly in the treatment groups supplemented with phytase (Table 4). The effect in yolk colour was consistent, and the improvement was significant during each of the 28-d evaluated periods (data not shown). The inclusion of phytase in the diet of laying hens has been shown to improve the availability of phytate phosphorus and other minerals such as calcium and zinc (Jalal and Scheideler, 2001), the availability of energy (Ravindran et al., 2000, 2001, Newkirk and Classen, 2001, Hughes et al., 2009) and fat (Um and Paik, 1999). Thus, the improvement in yolk colour observed in the present study could indirectly indicate improved nutrient digestibility, mainly fat by phytase supplementation, although a negative control diet would be required to confirm this. In addition, this observation might be partially explained by the higher level of corn present in the DS1 and DS2 diets compared to that in the PC diet (about 4\% more corn used in DS diets $v s$. PC), resulting in increased levels of lutein and zeaxanthin of the phytase supplemented diets. However, phytase treatment at 1,200 FTU $/ \mathrm{kg}$ had the same feed formulation as $300 \mathrm{FTU} / \mathrm{kg}$ but showed significantly lower colour L vs. PC, which might indicate that the effect of phytase on egg colour was more related to energy balance than corn inclusion levels. Other studies did not find significant differences in albumen index, yolk index, yolk percent or yolk colour with phytase supplementation (Jalal and Scheideler, 2001, Park et al., 2009, Lucky et al., 2014).

In the present study supplementing the DS1 diet with 300 FTU and the DS2 diet with 600 FTU resulted in non-significant differences in tibia ash, $\mathrm{Ca}$ and $\mathrm{P}$, compared to the PC diet (Table 4). Birds were healthy and no sign of any illness and leg weakness occurred during the test period. Therefore, the response to these three parameters indicated that applying the AvP and $\mathrm{Ca}$ contribution values for 300 and 600 FTU, and supplementing with phytase at respective dosages, could reduce total dietary $\mathrm{P}$ levels in layer diets without compromising bone integrity. When supplementing the diet formulated by subtracting the matrix values for 300 FTU from the PC diet with a higher phytase dose of 1,200 FTU/kg, tibia ash, $\mathrm{Ca}$ and $\mathrm{P}$ increased significantly compared to the $300 \mathrm{FTU} / \mathrm{kg}$ supplementation. The extra-dose of phytase used was able to liberate more $\mathrm{P}$ and $\mathrm{Ca}$ than $300 \mathrm{FTU} / \mathrm{kg}$, which resulted in a numerically higher tibia ash, Ca and P vs. PC. Although no significant differences were found between PC and the $300 \mathrm{FTU} / \mathrm{kg}$ phytase treatment, tibia ash was numerically lower in the 300 FTU/kg phytase treatment group. This may indicate that either the birds did not fully compensate for the $\mathrm{Ca}$ and $\mathrm{P}$ 
reduction or there is a $\mathrm{Ca}$ to $\mathrm{P}$ imbalance, as birds maintain the $\mathrm{Ca}$ to $\mathrm{P}$ ratio at approximately $2: 1$ in bones. Increasing phytase dose to 1,200 FTU would release more $\mathrm{P}$ and restore $\mathrm{Ca}$ : P balance, resulting in improved bone ash. It is worth mentioning that no leg weakness was observed in this study. Hughes et al. (2009) reported significantly improved tibia bone ash with the addition of phytase at 200 or $400 \mathrm{FTU} / \mathrm{kg}$ in 61-week-old laying hens diets deficient in P. Gao et al. (2013) showed significantly improved tibia ash in 66-week-old laying hens supplemented with phytase at 500 or $5,000 \mathrm{FTU} / \mathrm{kg}$ to a P-deficient diet. However, no differences in tibia ash were found in several other studies (Gordon and Roland, 1997, Van der Klis et al., 1997, Boorman and Gunaratne, 2001, Usayran et al., 2001, Sohail and Roland, 2002, Snow et al., 2005, Meyer and Parsons, 2011). The different responses observed in these studies may be explained by the differing levels of dietary P deficiency used and varying dietary $\mathrm{Ca}$ to $\mathrm{P}$ ratios.

Although overall results from the nine-month study showed no significant improvement in feed efficiency at higher phytase dose, the economic benefit, expressed as the feed costs per kg egg production of the groups supplemented with phytase were better than those fed the non-supplemented one (Table 5).

For comparison of phytase dose, overall results showed that phytase inclusion at $300 \mathrm{FTU} / \mathrm{kg}$ to DS1 diets maintained non-significant differences for egg production performance and egg quality parameters compared to PC, which indicated the nutritional values were met. Thus, no significant improvement on production parameters was seen with the extra phytase dose of 1,200 FTU/kg and no additional production benefit was seen with comparison of phytase at 1,200 FTU/kg vs $600 \mathrm{FTU} / \mathrm{kg}$.

Data showed that laying hens fed diet supplemented with $600 \mathrm{FTU} / \mathrm{kg}$ resulted in the lowest feed costs per $\mathrm{kg}$ egg mass. Phytase at $300 \mathrm{FTU} / \mathrm{kg}$ with $300 \mathrm{FTU}$ full matrix down spec reduced feed costs by $2.9 \%$, phytase

Table 5. Calculated feed costs per kg egg per treatment

\begin{tabular}{lllll}
\hline Treatment & T1 & T2 & T3 & T4 \\
Basal diet & PC & DS1 & DS2 & DS1 \\
Phytase, FTU/kg & 0 & 300 & 600 & 1,200 \\
\hline $\begin{array}{l}\text { Feed costs }{ }^{1}(€ / \mathrm{kg} \text { egg) for the } \\
\text { global trial }\end{array}$ & 0.536 & 0.520 & 0.493 & 0.497 \\
$\begin{array}{l}\text { Percentage improvement vs PC, } \\
\text { global 9 months }\end{array}$ & & -2.93 & -8.26 & -7.84 \\
\hline
\end{tabular}

${ }^{1}$ Calculations done for the specified combination of raw materials, prices from February 2016, when the trial was done, including phytase price. at 600 FTU/kg with 600 FTU full matrix down spec reduced feed costs by $8.3 \%$ while phytase at 1,200 FTU/ $\mathrm{kg}$ using 300 FTU full matrix down spec showed 7.8\% cost reduction compared to PC.

Better economic efficiency values with supplementation of phytase to laying hen diets have been previously reported (Ligeiro et al., 2009, El-Shikha et al., 2013). Costa et al. (2008) suggested that adjusting the diet formulation by reducing nutrients and adding exogenous enzymes in order to restore nutritional value of the standard diet leads to a reduction in production costs.

On comparison of feed cost per kg egg mass for each phase, phytase at $600 \mathrm{FTU} / \mathrm{kg}$ added to DS2 diets showed consistently higher economic benefit compared to phytase at $300 \mathrm{FTU} / \mathrm{kg}$ or $1200 \mathrm{FTU} / \mathrm{kg}$ added to DS1. The economic benefit was higher in the second and third three months than first three months (data not shown), which might be explained by the difference in feed formulation. The diets for first three months had higher CP levels (about 2\% higher) than the diets in the second and third trimester periods. This indicated that production benefits could be higher in a diet formulated with lower protein. This finding may imply that older birds benefit more from a higher dose of phytase supplementation (e.g. 600 FTU), due to reduced feed efficiency with increasing age.

Based on the cost benefit calculation, phytase at 600 FTU added to DS2 diets is the optimal dosing approach, which resulted in higher production benefit, compared to phytase at 300 FTU or 1,200 FTU added to DS1. Using phytase dose at 1,200 FTU/kg showed improved bone mineralisation vs 300 FTU, which was measured only at the end of the study where diets contained low P levels (total $\mathrm{P}$ content was $0.59,0.44$ and 0.41 respectively in PC, DS1 and DS2 diets). This may indicate that a high dose of phytase may be beneficial for mineralisation in older birds, however, more research should be carried out to test this hypothesis.

Based on the results of this study, it can be recommended that under current practice for commercial diets formulated based on ISA breeder recommendations, when supplementing phytase in the diets, the nutrients contribution of $\mathrm{P}, \mathrm{Ca}, \mathrm{ME}$, dig $\mathrm{AA}$ and $\mathrm{Na}$ at corresponding phytase dose should be applied. Phytase dose at $600 \mathrm{FTU} / \mathrm{kg}$ added to diets with reduction of above mentioned nutrients can result in better production benefit than the traditional dose of $300 \mathrm{FTU} / \mathrm{kg}$ with corresponding nutrients reduction, or dosing at 1,200 FTU/kg with 300 FTU matrix values. 


\section{Conclusions}

The data from this commercial feeding trial indicated that supplementation with Buttiaxella phytase at doses of 300 FTU $/ \mathrm{kg}$ could replace $55 \mathrm{kcal} / \mathrm{kg}$ of $\mathrm{AME}_{\mathrm{n}}, 0.325 \% \mathrm{CP}$, $0.134 \%$ Ca, $0.149 \%$ av.P, $0.0147 \%$ dig. Lys, $0.0149 \%$ dig. Met+Cys, $0.0128 \% \operatorname{dig}$ Thr and $0.002 \%$ dig. Trp, and at dose of $600 \mathrm{FTU} / \mathrm{kg}$ could replace $60 \mathrm{kcal} / \mathrm{kg}$ of $\mathrm{AME}_{\mathrm{n}}$, $0.607 \%$ CP, $0.159 \%$ Ca, $0.177 \%$ av.P, $0.0271 \%$ dig. Lys, $0.0275 \%$ dig. Met+Cys, $0.0237 \%$ dig Thr and $0.0037 \%$ dig. Trp in diets formulated based on ISA breeder recommendations. Applying these nutrient contributions maintained the egg production, BW, egg quality parameters, but with an increased egg colour compared to PC. The supplementation of higher phytase dose of 1,200 FTU to the $300 \mathrm{FTU} / \mathrm{kg}$ matrix reduced diet did not outperform laying performance or egg quality, but improved tibia mineralisation. Supplementation of phytase resulted in cost benefit; the best economic efficiency value during the whole experimental period was recorded with phytase at $600 \mathrm{FTU} / \mathrm{kg}$ when full matrix values are used. Under current practice when commercial diets are formulated based on ISA breeder recommendations, lowering diet nutrient density while supplementing with phytase reduces the overall diet cost, which should contribute to the profitability of the production of eggs.

\section{References}

AOAC (2000) Official Methods of Analysis. Association of Official Analytical Chemist. EEUU.

Boorman K.N. and Gunaratne S.P. (2001) Dietary phosphorus supply, egg-shell deposition and plasma inorganic phosphorus in laying hens. British Poultry Science, 42: 81-91.

Costa F.G.P., Goulart C.C., Figueiredo D.F., Oliveria C.F.S. and Silva J.H.V. (2008) Economic and environmental impact of using exogenous enzymes on poultry feeding. International Journal of Poultry Science, 7: 311-314.

El-Shikha T.B., Attia A.I., Soliman M.M. and Mahrose K.H.M. (2013) Effect of microbial phytase supplementation on the productive performance of laying hens fed different levels of dietary calcium and available phosphorus. Zagazig Journal of Agricultural Research, 40: 81-95.

FASS (2010). Guide for the care and use of agricultural animals in research and teaching. Federation of Animal Science Societies 2010, Champaign (IL).

FEDNA (2010) Guidelines of the Spanish foundation for development of animal nutrition for the formulation of compound feeds, in: de Blas C., García P., Mateos G.G. (Eds), Fundación Española para el Desarrollo de la Nutrición Animal, E.T.S.I.A. Madrid Polytechnical University, Spain.

Gao C.Q., Ji C., Zhang J.Y., Zhao L.H. and Ma Q.G. (2013) Effect of a novel plant phytase on performance, egg quality, apparent ileal nutrient digestibility and bone mineralisation of laying hens fed cornsoybean diets. Animal Feed Science and Technology, 186: 101-105.

Ghosh M., Huynh D., Sodhi S.S., Sharma N., Kim J.H., Kim N., Mongre R.K., Park W.P., Shin H.S., Ko S., Oh S., Choi C.W.,
Oh S.J. and Jeong D. (2015) Impact of a novel phytase derived from Aspergillus nidulans and expressed in transgenic Lemna minor on the performance, mineralisation in bone and phosphorous excretion in laying hens. Pakistan Veterinary Journal, 35: 360-364.

Gordon R.W. and Roland Sr. D.A. (1997) Performance of commercial laying hens fed various phosphorus levels, with and without supplemental phytase. Poultry Science, 76: 1172-1177.

Hughes A.L., Dahiya J.P., Wyatt C.L. and Classen H.L. (2008) The efficacy of quantum phytase in a forty-week production trial using white Leghorn hens fed corn-soybean meal based diets. Poultry Science, 87: 1156-1161.

Hughes A.L., Dahiya J.P., Wyatt C.L. and Classen H.L. (2009) Effect of Quantum phytase on nutrient digestibility and bone ash in White Leghorn laying hens fed corn-soybean meal-based diets. Poultry Science, 88: 1191-1198.

ISA Nutrition Management Guide. (2009) ISA Brown commercial layers. Hendrix Genetics, Villa 'de Körver', P.O. Box 114, 5830 AC Boxmeer, The Netherlands. isa-poultry.com

Jalal M.A. and Scheideler S.E. (2001) Effect of supplementation of two different sources of phytase on egg production parameters in laying hens and nutrient digestibility. Poultry Science, 80: 1463-1471.

Jalal M.A., Scheideler S.E. and Wyatt C. (1999) Effects of phytase supplementation on egg production parameters and amino acid digestibilities. Poultry Science, 78(Suppl. 1): 74.

Kornegay E., Denbow D., Yi Z. and Ravindran V. (1996) Response of broilers to graded levels of microbial phytase added to maizesoyabean-meal-based diets containing three levels of nonphytate phosphorus. British Journal of Nutrition, 75: 839-852.

Kozłowski K. and Jeroch H. (2011) Efficacy of different levels of Escherichia coli phytase in hens fed maize-soyabean meal diets based diets with a decreased non-phytate phosphorus content. Journal of Animal and Feed Sciences, 20: 224-235.

Li W., Angel R., Kim S.-W., Brady K., Yu S. and Plumstead P.W. (2016) Impacts of dietary calcium, phytate, and nonphytate phosphorus concentrations in the presence or absence of phytase on inositol hexakisphosphate (IP6) degradation in different segments of broilers digestive tract. Poultry Science, 95: 581-585.

Li W., Angel R., Kim S.-W., Jiménez-Moreno E., ProszkowiecWeglar M. and Plumstead P.W. (2015) Age and adaptation to Ca and P deficiencies: 2. Impacts on amino acid digestibility and phytase efficacy in broilers. Poultry Science, 94: 2917-2931.

Liebert F., Htoo J.K. and Sunder A. (2005) Performance and nutrient utilisation of laying hens fed low-phosphorus corn-soybean and wheat-soybean diets supplemented with microbial phytase. Poultry Science, 84: 1576-1583.

Ligeiro E.C., Junqueira O.M., da Silva Filardi R., de Laurentiz A.C., Ferreira Duarte K. and Andrade Marchizeli P.C. (2009) Availação da matriz nutricional da enzima fitase em rações contendo sorgo para poedeiras comerciais. Revista Brasileira de Zootecnia, 38: 1948-1955.

Lucky N.J., Howlider M.A.R., Alam M.A. and Ahmed M.F. (2014) Effect of dietary exogenous phytase on laying performance of chicken at older ages. Bangladesh Journal of Animal Science, 43: 52-55.

Meyer E. and Parsons C. (2011) The efficacy of a phytase enzyme fed to Hy-Line W-36 laying hens from 32 to 62 weeks of age. Journal of Applied Poultry Research, 20: 136-142.

Namkung H. and Leeson S. (1999) Effect of phytase enzyme on dietary nitrogen corrected apparent metabolisable energy and ileal digestibility of nitrogen and amino acids in broiler chicks. Poultry Science, 78: $1317-1319$.

Newkirk R.W. and Classen H.L. (2001) The non-nutritional impact of phytate in canola meal fed to broiler chicks. Animal Feed Science and Technolpgy, 91: 115-128.

Panda A.K., Rama Rao S.V., Raju M.V.L.N. and Bhanja S.K. (2005) Effect of microbial phytase on production performance of White leghorn layer fed on a diet low in nonphytate phosphorus. British Poultry Science, 46: 464-469. 
Park K.W., Rhee A.R., Um J.S. and Paik I.K. (2009) Effect of dietary available phosphorus and organic acids on the performance and egg quality of laying hens. Journal of Applied Poultry Research, 18: 598-604.

Ravindran V.S., Cabahug G., Ravindren G., Shelle P.H. and Bryden W.L. (2000) Response of broiler chickens phytase supplementation as affected by dietary phytic acid and non phytate phosphours level. Effect of apparent metabolisable energy nutrient digestibility and nutrients retention. British Poultry Science, 41: 193-200.

Ravindran V., Morel P.C.H., Patridge G.G., Hruby M. and Sands J.S. (2006) Influence of an Escherichia coli-derived phytase on nutrient utilisation in broiler starters fed diets containing varying concentrations of phytic acid. Poultry Science, 85: 82-89.

Ravindran V.S., Selle P.H., Ravindran G., Morel P.H., Kies A.K. and Bryden W.L. (2001) Microbial phytase improves performance, apparent metabolisable energy, and ileal amino acid digestibility of broilers fed a lysine-deficient diet. Poultry Science, 80: 338-344.

Rutherfurd S.M., Chung T.K., Morel P.C.H. and Moughan P.J. (2004) Effect of microbial phytase on ileal digestibility of phytate phosphorus, total phosphorus, and amino acids in a low-phosphorus diet for broilers. Poultry Science, 83: 61-68.

Shelton J., Southern L., Gaston L. and Foster A. (2004) Evaluation of the nutrient matrix values for phytase in broilers. Journal of Applied Poultry Research, 13: 213-221.

Snow J.L., Rafacz K.A., Utterback P.L., Utterback C.W., Leeper R.W. and Parsons C.W. (2005) Hy-Line W-36 and Hy-Line W-98 laying hens respond similarly to dietary phosphorus levels. Poultry Science, 84: 757-763.

Sohail S.S. and Roland Sr. D.A. (2002) Influence of dietary phosphorus on performance of Hy-Line W-36 hens. Poultry Science, 81: 75-83.

Truong H.H., Yu S., Moss A.F., Partridge G.G., Liu S.Y. and Selle P.H. (2016) Phytase inclusions of 500 and 2000 FTU/kg in maizebased broiler diets impact on growth performance, nutrient utilisation, digestive dynamics of starch, protein $(\mathrm{N})$, sodium and IP6 phytate degradation in the gizzard and four small intestinal segments. Animal Feed Science and Technology, 223: 13-22.

Um J S. and Paik I.K. (1999) Effects of microbial phytase supplementation on egg production, eggshell quality and mineral retention of laying hens fed different levels of phosphorus. Poultry Science, 78: 75-79.

Usayran N., Farran M.T., Awadallah H.H.O., Al-Hawi I.R., Asmar R.J. and Ashkarian V.M. (2001) Effects of added dietary fat and phosphorus on the performance and egg quality of laying hens subjected to a constant high environmental temperature. Poultry Science, 80: 1695-1701.

Valaja J., Tuunainen P., Koivunen E. and Kühn I. (2013) Phytase supplementation improved $\mathrm{P}$ utilisation of the laying hens fed barley-oats soybean meal based diets. Proceedings of the 19 th European Symposium on Poultry Nutrition, Potsdam, Germany, pp. 183-184.

Van der Klis J.D., Versteegh H.A.J., Simons P.C.M. and Kies A.K. (1997) Efficacy of phytase in corn-soybean meal-based diets for laying hens. Poultry Science, 76: 1535-1542.

White E., Bold R., Wealleans A.L., Dersjant-Li Y. and Kwakernaak S. (2016) Effect of a Buttiauxella phytase on nutrient digestibility and performance in laying hens fed a diet without supplemental inorganic phosphorus. Proceeding of WPS A, Chester, UK.

Yu S., Kvidtgaard M.F., Isaksen M.F. and Dalsgaard S. (2014) Characterisation of a mutant Buttiauxella phytase using phytic acid and phytic acid-protein complex as substrates. Animal Science letters, 1: $18-32$.

Żyła K., Mika M., Świątkiewicz S., Koreleski J., and Piironen J. (2011) Effects of phytase B on laying performance, eggshell quality and on phosphorus and calcium balance in laying hens fed phosphorus-deficient maize-soybean meal diets. Czech Journal of Animal Science, 56: 406-413. 